\title{
The Antecedents of Green Car Purchase Intention among Malaysian Consumers
}

\author{
Yi Jin Lim, Selvan Perumal, Norzieiriani Ahmad
}

\begin{abstract}
This study aims to empirically examine the relationships among social influence, green labeling, economic incentives, environmental attitude, environmental knowledge, past green purchase behavior and green car purchase intention among the Malaysian consumers. A multi-stage sampling process with proportionate stratified sampling in the first stage and systematic mall intercept method in the second stage was applied in this study. Thereafter, a questionnaire survey was done among consumers aged 18 and above that visiting car dealers, namely Honda, Toyota and Nissan from the two representative states of Malaysia namely Penang and Kuala Lumpur. 417 out of 500 questionnaires distributed were returned back for data analysis using SmartPLS v.3 software. The results show that green labeling, economic incentives, environmental attitude are direct antecedents of green car purchase intention in Malaysia. However, social influence, environmental knowledge and past green purchase behavior do not have any influence on green car purchase intention in Malaysia. Lastly, implications of this study and limitations found in this study are discussed.
\end{abstract}

Index Terms-Economic Incentives; Environmental Attitude; Environmental Knowledge; Green Car Purchase Intention; Green Labeling; Past Green Purchase Behavior; Social Influence

\section{INTRODUCTION}

Transport sector has occupied about $60 \%$ of world oil consumption and $25 \%$ of total world $\mathrm{CO}_{2}$, which is worrying [1]. Therefore, green car policies were introduced by most of the countries around the world to produce low emission and energy-efficient cars [2]. As green cars are gaining popularity in 2017 while some countries declaring to eliminate internal combustion engine progressively by 2040 [2], the trend of going green has also gradually invaded to Asian region and one of them is Malaysia. However, the sales of green cars still a far cry as compared to the sales of internal combustion engine powered car [3]. It was also happened in Malaysia whereby there are only around $2 \%$ of over 600,000 units of vehicles sold annually [4]. Added to that, green car sales appear to be fragile to the economic recession [5] as green cars typically charged with higher price due to the invented technologies that different from internal combustion engine used by conventional cars. Moreover, it was noticed that the future of EVs in Malaysia is still unpredictable as the sales of EVs are facing difficulty to attract the consumers particulary with the poor infrastructure development in the EV industry [6].

Yi Jin Lim is with the School of Business Management, Universiti Utara Malaysia, 06010 Sintok, Malaysia (e-mail: asdeyu@gmail.com).

Selvan Perumal is with School of Business Management, Universiti Utara Malaysia, 06010 Sintok, Malaysia (e-mail: selvan@uum.edu.my).

Norzieiriani Ahmad is with School of Business Management, Universiti Utara Malaysia, 06010 Sintok, Malaysia (e-mail: norzie@uum.edu.my).
Therefore, it is prompted to promote green cars among Malaysian citizens in order to impede environmental deterioration while moving towards more sustainable economy.

Although wide-ranging of studies have been done on the environmental attitudes, environmental knowledge, past behavior, social influence, green labeling and economic incentives, most of them are investigated separately in different studies. To detail up the matters, previous studies have been done on investigating the influence of environmental knowledge, environmental attitudes and past behavior (recycling participation) [7]; social influence, perceived environmental knowledge, recycling participation and green labeling [8]; environmental attitude and recycling participation [9]; government incentives, knowledge, attitude and social influence [10] on green purchasing context in different studies. This means there is lack of empirical research that concatenates these variables together to cover their impacts. Moreover, the inconsistent results in previous studies on predicting green product purchases [11] has raise curiosity of the researcher to further investigate these variable. Hence, the integration of environmental attitude, environmental knowledge, past green purchase behavior, social influence, green labeling and economic incentives per se as the predictors in influencing green purchase intention should be further explored.

To address this concern, this study attempted to empirically examine the relationships among social influence, green labeling, economic incentives, environmental attitude, environmental knowledge, past green purchase behavior and green car purchase intention among the Malaysian consumers. This empirical research is therefore to provide useful guidelines to improve future research.

\section{LITERATURE REVIEW}

\section{A. Social influence}

According to [12] and [13], social influence mirrors an individual's perceived social pressure to behave in certain behavior. It is because individuals often share their perspective, thought and value with people who they interact with [14], [15]. This could be included parents, siblings, peers, teachers or even entertainers and athletes [16]. In other words, opinion of those people that are important to them have certain impact on the individual's decision when dealing with products purchase [17].

In the green purchasing context, it was found that most of the research were concentrating on personal predispositions and often neglected the mechanism of how social influence affect sustainable behavior [18], [19]. Yet, reference [20] have argued that social norms and generating societal influence are the key factor to affect green purchase 
behavior of consumers from different age group. Added to that, several studies have shown that social influence has positive and significant impact on green purchasing behavior [8], [9], [20]-[22]. It has also been proven that social influence is the most important variable to influence green purchases such as the research by [8], [21], [22]. In contrary, [23] have found that 157 undergraduate students from an Australian university did not influenced by others when making decision on whether to purchase organic foods. Reference [24] further supported that social influence insignificantly affect purchasing patterns of eco-friendly cosmetics and beauty care products among the female customers in Mauritius. Hence, based on the extensive reviews within the literature, hypothesis is generated as follow:

H1: Social influence significant positively predict green car purchase intention.

\section{B. Labeling}

Labels is a small piece of paper with diagrams or detailed information of the products as a part of good packaging [25]. In addition, definition by [26] point towards the diverse messages and complicated minglement of information that constitute a label. Reference [27] advocated that label is not simply a piece of paper as a part of packaging but it is also an important element to influence consumer purchasing decisions.

Reference [28] that applied Theory of Planned Behavior (TPB) have found that green label is the best predictor among others (environmental attitude and long term orientation) of green purchase intention for consumers in Malaysia. It was supported by [29] that there are positive significant relationship between green label and green purchase intention. Although reference [8] in their related study have found significant relationship between green labeling and green purchase behavior by applied Social Cognitive Theory (SCT), the result have indicated weak connection. Similiarly, [30] also indicated the same results whereby there are significant but weak relationship between green label and green purchase intention. [31] that conducted their research in Penang, Malaysia, found differences suggesting that green labeling did not have significant effect on green purchase behavior. Also, [32] have similar finding that indicated insignificant result between green label and green purchase intention. Since there is inconsistency in previous studies, several researches have suggested to examine green labeling in green purchasing studies [25]. Subsequently, the hypothesis is suggested as below:

H2: Green labeling significant positively predict green car purchase intention.

\section{Economic Incentives}

Since environmental assets are freely available or underpriced, they are often used and squandered excessively by human being, that subsequently resulting in environmental damage[33]. Economic incentives can rectify this condition by setting a price for environmental damage or creating ownership rights to environmental goods[33]. Added to that, economic incentives by decreasing the upfront cost of the new technology and promote greater sales through defrayed cost are believed to lure market development of new technologies[34].
There have been several studies in the literature reporting the predictive power of incentives in consumer purchase decision. Reference [10] found that government incentives are the most crucial factors than attitude and subjective norm to influence green housing purchase intention of young consumers aged 18 to 30 years old in China. It was in agreement with the research by reference [35] that exemption from purchase tax and value added tax (VAT) are significant factor to lure consumers to electric vehicle (EV) adoption in Norway. However, from their study, it can be seen that EV adoption is highly depends on the size of the incentives provided as exemption from road tolling or bus lane access are discovered not decisive factors. As Norway is the country that has highest market share in the world, with $39.2 \%$, based on the data given by Internation Energy Agency (IEA) [36], and one likely reason might be due to their strategies of providing strong incentives to motivate their citizens to purchase electric cars [35]. Their visible success of incentive policies makes Norway a role model to learn from for other countries that aim to increase sales of the green vehicles [35]. Yet, suprisingly, this variable has rarely been empirically examined its viability to influence green car purchases in Malaysia. Based on previous reviews within the literature, hypothesis is created as below:

$\mathrm{H} 3$ : Economic incentives significant positively predict green car purchase intention.

\section{Attitude}

According to reference [37], most of the attitude-behavior relationship could be obtained from several psychological theories such as Theory of Planned Behavior (TPB), Social Cognitive Theory (SCT) and Technology Acceptance Model (TAM). Although significant relationship was found in most of the studies between attitude and consumer purchasing behavior, the effect of attitude did not play the same consistent outcome with green purchasing behavior. Reference [38] who applied Theory of Reasoned Action (TRA) to test the mediating effect of green purchasing atittudes on green purchasing behavior have ascertained that attitude is the better choice compared to intention to influence consumer behavior. However, several theories have proven that not only attitude that could affect behavior, there are also various factors that have guided consumers towards purchasing behavior while in the meantime, work upon the potency of attitude-behavior relationship [11]. A study by [39] and [15] who conducted the research in developing countries have proven that environmental attitude is the most influential factor to predict green purchasing behavior. Similarly, reference [40] and [41] that conducted their studies in developing countries in Iran and Malaysia respectively have also found significant relationship between environmental attitude and sustainable purchasing behavior.

Yet, [42], [43] and [44] that conducted the research in developed country have found no significant relationship between environmental attitude and green purchasing behavior. It might be due to the existance of attitudebehavioral gaps [45] whereby the consumers are not transforming their concern to the environment into the real actions including spend money on green products and they are dubious on the quality of the products that claimed to be environmental friendly [46]. Similarly, reference [14], [47] and [48] that conducted their studies in developing countries 
(Malaysia) have also found insignificant relationship. The inconsistency and insignificant results found in previous studies might be due to these authors only focused on one state or one university in respective countries. Therefore, in order to close the gaps, the researcher will undergo this study in several cities in Malaysia. Hereafter, the hypothesis is generated as below:

H4: Environmental attitude significant positively predict green car purchase intention.

\section{E. Knowledge}

Knowledge towards a subject matter contribute significant role in the research of consumer purchasing behavior, therefore more research is needed in relevant fields. Reference [38] and [40] indicated that knowledge was the most important predictor to influence green purchasing behavior. Reference [49] agreed that knowledge is one of the important factor when examining green product purchases. While [8] who selected college students also found that knowledge on green issues is the second best predictor after environmental atittude to influence green purchasing behavior. It is because consumers with higher environmental knowledge are more conscious towards ecolabels that will assist them in interpreting the information on the labels, thus will influence their purchasing decision [50]. The result is consistent with other researchers such as [8], [20], [21], [41], [48], [51] and [52] that environmental knowledge will lead to consumers' green purchasing behavior. Research finding by [53] also pointed towards the importance of environmental knowledge on forming positive attitudes towards green vehicles that will subsequently lead to green vehicles purchase intention. In contrast, the study by [54] found no significant relationship between quality knowledge, cost knowledge and green knowledge and purchase intention of remanufactured products which grounded on prospect theory. Similarly, reference [31] indicated that environmental knowledge did not influence environmental friendly purchasing behavior of Malaysian consumers.

Apart from the inconsistent findings in previous studies, it has been shown that there are limited theoretical approached that investigate the impact of knowledge on green product purchasing behavior in current literature [55]. Added to that, given the fact that the effect of knowledge on environmentally friendly products are crucial for a consumer, the current situation showed that there is still lack of relevant knowledge among consumers [55], [56]. Based on critical review on current literature, the hypothesis is created as below:

H5: Environmental knowledge significant positively predict green car purchase intention.

\section{F. Past Behavior}

Past behavior is an action or response of an individual that resulted from internal or external impetus in the past while habit is an individual's automatic response or action produced from mental manifestation [57]. Although there is slightly difference when defining past behavior and habits, reference [12] advocated that both past behavior and habit are anything but identical. In this study, past green product purchase behavior represents the past behavior that the consumers practice in their daily lifestyle of how frequent the consumers purchase products that are "green".
Reference [58] asserted that practical awareness such as consumers' habits and lifestyle is more prominent than discursive awareness in grasping consumer behavior. In another study, reference [59] asserted that undertaking of pro-environmental behavior enhances the tendency of performing in another pro-environmental behavior. Similarly, reference [56] and [60] that studied in organic clothing purchasing behavior have found that consumer purchasing behavior was influenced by past environmental value and past environmentally friendly behavior respectively.

However, reference [61] have revealed that past online shopping experience is a prominent factor that influence perceived risks and benefits of internet shopping but past internet experience has only finite impact on perceptions and online purchase intention of apparels among mature consumers. In a recent study conducted in Malaysia, reference [62] have disclosed that past online purchase experience did not exhibit a beneficial tool to influence postusage usefulness which grounded on model of information technology continuation and contingency framework.

Based on the extensive review within the literature, although past behavior has been examined in ecological behavioral research, the operationalization of this variable was manifold or either it was not been investigated simultaneously with other variables such as attitudes and social norms as the antecedents for green behavior [63]. Hence, past green purchase behavior which indicates past experience is to be studied in this research with other variables as discussed above. Following the extensive reviews, the hypothesis is suggested as below:

H6: Past green purchase behavior significant positively predict green car purchase intention.

\section{RESEARCH METHODOLOGY}

\section{A. Sample and Data Collection}

The relationships of social influence, green labeling, economic incentives, environmental attitude, environmental knowledge, past green purchase behavior and green car purchase intention were investigated. After conducting an extensive review of literature, a consumer survey was designed and conducted using an instrument validated through pre-test conducted among 8 marketing experts and pilot test using 30 respondents that visiting car dealers of Honda, Toyota and Nissan in Penang and Kuala Lumpur, Malaysia. The results shown no items were deleted after pre-test and pilot test. The 30 respondents that have been participated in the pilot test were withdrawn from participating in the following stage, which is the actual data collection. A multi-stage sampling process with proportionate stratified sampling in the first stage and systematic mall intercept method in the second stage was applied. The main data collection was done among consumers aged 18 and above that visiting car dealers of Honda, Toyota and Nissan from the two representative states of Malaysia namely Penang and Kuala Lumpur. A total number of 500 questionnaires were distributed during the period of $11^{\text {st }}$ July, 2018 till $30^{\text {th }}$ November, 2018 with 417 returned and usable questionnaires, indicating $83.4 \%$ response rates. Hereafter, the data was interpreted using analytical tools including SPSS version 21 and SmartPLS version 3.2.8. 


\section{B. Measurements}

By adapting and/or adopting valid scale items from the previous studies, green car purchase intention was measured using 5-item scales adapted from [64] and [65]. Social influence was measured using 6-item scales adopted from [9] and [66]. Green labeling was measured using 4-item scales adapted from [30]. Economic incentives were measured using 6-item scales adapted from [67]. Environmental attitude was measured using 4-item scales adapted from [68]. Environmental knowledge was measured using 6-item scales adopted from [21]. Past green purchase behavior was measured using 6-item scales adapted from [66]. Participants answered these items using 7-point Likert type scales ranging from 1 (strongly disagree) to 7 (strongly agree) and 1 (never) to 7 (always).

\section{RESULTS}

\section{A. Descriptive Analysis}

The results of descriptive statistics presented in Table I showed that all variables and their dimensions possessed a mean ranging from 4.3181 to 5.5811 which were all above the average value. In other words, all of these mean values indicated the respondents agreed with the questions in general. The standard deviation of all dimensions ranged from 1.07767 to 1.40907 reflected that the existence of considerably acceptable variability within the data set. The results demonstrated that every studied variable had different responses from the respondents, thus implied the existence of acceptable changes in responses. In short, all the constructs min, max, mean and standard deviation values are listed in Table I as shown below.

Table I. Summary of the Descriptive Statistics of the Study Variables

\begin{tabular}{lccccc}
\hline \hline Construct & $\mathrm{N}$ & Min & Max & Mean & $\begin{array}{l}\text { Std. } \\
\text { Deviation }\end{array}$ \\
\hline $\begin{array}{l}\text { Green car purchase } \\
\text { intention }\end{array}$ & 417 & 1.00 & 7.00 & 5.5463 & 1.20008 \\
$\begin{array}{l}\text { Environmental attitude } \\
\text { Environmental }\end{array}$ & 417 & 1.00 & 7.00 & 5.2266 & 1.15201 \\
knowledge & 417 & 1.00 & 7.00 & 5.3617 & 1.09061 \\
$\begin{array}{l}\text { Past green purchase } \\
\text { behavior }\end{array}$ & 417 & 1.00 & 7.00 & 4.8609 & 1.21594 \\
$\begin{array}{l}\text { Social influence } \\
\text { Green labeling }\end{array}$ & 417 & 1.00 & 7.00 & 5.5811 & 1.16093 \\
Economic incentives & 417 & 1.00 & 7.00 & 4.3181 & 1.40907 \\
\hline \hline
\end{tabular}

\section{B. Evaluation of the Measurement Model}

Internal consistency or reliability of the indicators was assessed using PLS-SEM by means of Cronbach's alpha and composite reliability (CR). However, due to several drawbacks found when using Cronbach's alpha in evaluating the reliability of the instruments, therefore this study applied a more appropriate alternative reliability measure which is CR. It is to assess the consistency between an indicator or a set of indicators and the latent variable to be measured [69]. From Table 3, it showed that all the constructs have excellent inter-item consistency with Cronbach's alpha recorded at between 0.862 and 0.933 . In addition, composite reliability (CR) also indicated satisfactory and recorded at between 0.907 and 0.949 [70]. To measure the validity of the measurement model, factor loadings and Average Variance Extracted (AVE)) were used to measure convergent validity [70]. A satisfactory level of
AVE should be at least 0.5 or higher to show that a latent variable can explain the variance of its indicators [70], [71]. The authors further advocated that a factor loading of equal to or greater than 0.7 is also considered as satisfactory. Based on the result, all the constructs have met the requirement of factor loading of equal to or greater than 0.7 while AVE also recorded at satisfactory level of more than 0.5 , which ranging between 0.677 and 0.790 . Hence, there are no items deleted at these stage.

Table II. Internal Consistency and Convergent Validity Analysis

\begin{tabular}{|c|c|c|c|c|c|}
\hline Constructs & Items & Loading & $\begin{array}{l}\text { Cronbach's } \\
\text { Alpha }\end{array}$ & CR & AVE \\
\hline \multirow{5}{*}{$\begin{array}{l}\text { Green car } \\
\text { purchase intention }\end{array}$} & GPI1 & 0.844 & \multirow{5}{*}{0.933} & \multirow{5}{*}{0.949} & \multirow{5}{*}{0.790} \\
\hline & GPI2 & 0.924 & & & \\
\hline & GPI3 & 0.900 & & & \\
\hline & GPI4 & 0.904 & & & \\
\hline & GPI5 & 0.873 & & & \\
\hline \multirow{4}{*}{$\begin{array}{l}\text { Environmental } \\
\text { attitude }\end{array}$} & EA1 & 0.815 & \multirow{4}{*}{0.862} & \multirow{4}{*}{0.907} & \multirow{4}{*}{0.709} \\
\hline & EA2 & 0.875 & & & \\
\hline & EA3 & 0.900 & & & \\
\hline & EA4 & 0.772 & & & \\
\hline \multirow{6}{*}{$\begin{array}{l}\text { Environmental } \\
\text { knowledge }\end{array}$} & EK1 & 0.833 & \multirow{6}{*}{0.923} & \multirow{6}{*}{0.939} & \multirow{6}{*}{0.721} \\
\hline & EK2 & 0.853 & & & \\
\hline & EK3 & 0.856 & & & \\
\hline & EK4 & 0.870 & & & \\
\hline & EK5 & 0.875 & & & \\
\hline & EK6 & 0.804 & & & \\
\hline \multirow{6}{*}{$\begin{array}{l}\text { Past green } \\
\text { purchase behavior }\end{array}$} & PGP1 & 0.830 & \multirow{6}{*}{0.914} & \multirow{6}{*}{0.933} & \multirow{6}{*}{0.698} \\
\hline & PGP2 & 0.882 & & & \\
\hline & PGP3 & 0.759 & & & \\
\hline & PGP4 & 0.801 & & & \\
\hline & PGP5 & 0.883 & & & \\
\hline & PGP6 & 0.850 & & & \\
\hline \multirow{6}{*}{ Social influence } & SI1 & 0.799 & \multirow{6}{*}{0.904} & \multirow{6}{*}{0.926} & \multirow{6}{*}{0.677} \\
\hline & SI2 & 0.894 & & & \\
\hline & SI3 & 0.880 & & & \\
\hline & SI4 & 0.817 & & & \\
\hline & SI5 & 0.820 & & & \\
\hline & SI6 & 0.712 & & & \\
\hline \multirow{4}{*}{ Green labeling } & GL1 & 0.776 & \multirow{4}{*}{0.878} & \multirow{4}{*}{0.916} & \multirow{4}{*}{0.733} \\
\hline & GL2 & 0.859 & & & \\
\hline & GL3 & 0.894 & & & \\
\hline & GL4 & 0.891 & & & \\
\hline \multirow{6}{*}{$\begin{array}{l}\text { Economic } \\
\text { Incentives }\end{array}$} & EI1 & 0.757 & \multirow{6}{*}{0.929} & \multirow{6}{*}{0.945} & \\
\hline & EI2 & 0.763 & & & \\
\hline & EI3 & 0.899 & & & 0.743 \\
\hline & EI4 & 0.912 & & & \\
\hline & EI5 & 0.914 & & & \\
\hline & EI6 & 0.910 & & & \\
\hline
\end{tabular}

\section{Assessment of Structural Model}

After confirmed the Variance Inflation Factor (VIF) values that obtained through Multicollinearity test are lower than the value of 3.3 [72] as seen in Table III, which indicating the non-existence of collinearity issues, the subsequent stage of assessing structural model involved statistically testing the proposed hypothesized relationships using bootstrapping procedure in SmartPLS executed at 1000 subsamples to empirically confirm the existence of proposed path relationships. This study utilized one-tailed test seeing that the hypothesis testing is directional. For one tailed test, the critical value for significance level of 1 percent $(\alpha=0.01), 5$ percent $(\alpha=0.05)$ and 10 percent $(\alpha=$ $0.10)$ are $2.33,1.645$ and 1.28 respectively [73]. Hereafter, the results shown that the factors of green labeling $(\beta=0.141$, $\mathrm{t}=2.275, \mathrm{p}<0.05)$, economic incentives $(\beta=0.272, \mathrm{t}=5.628$, $\mathrm{p}<0.01)$ and environmental attitude $(\beta=0.311, \mathrm{t}=4.483$, 
$\mathrm{p}<0.01$ ) have a significant and positive impacts, thus $\mathrm{H} 2, \mathrm{H} 3$ and $\mathrm{H} 4$ are supported.

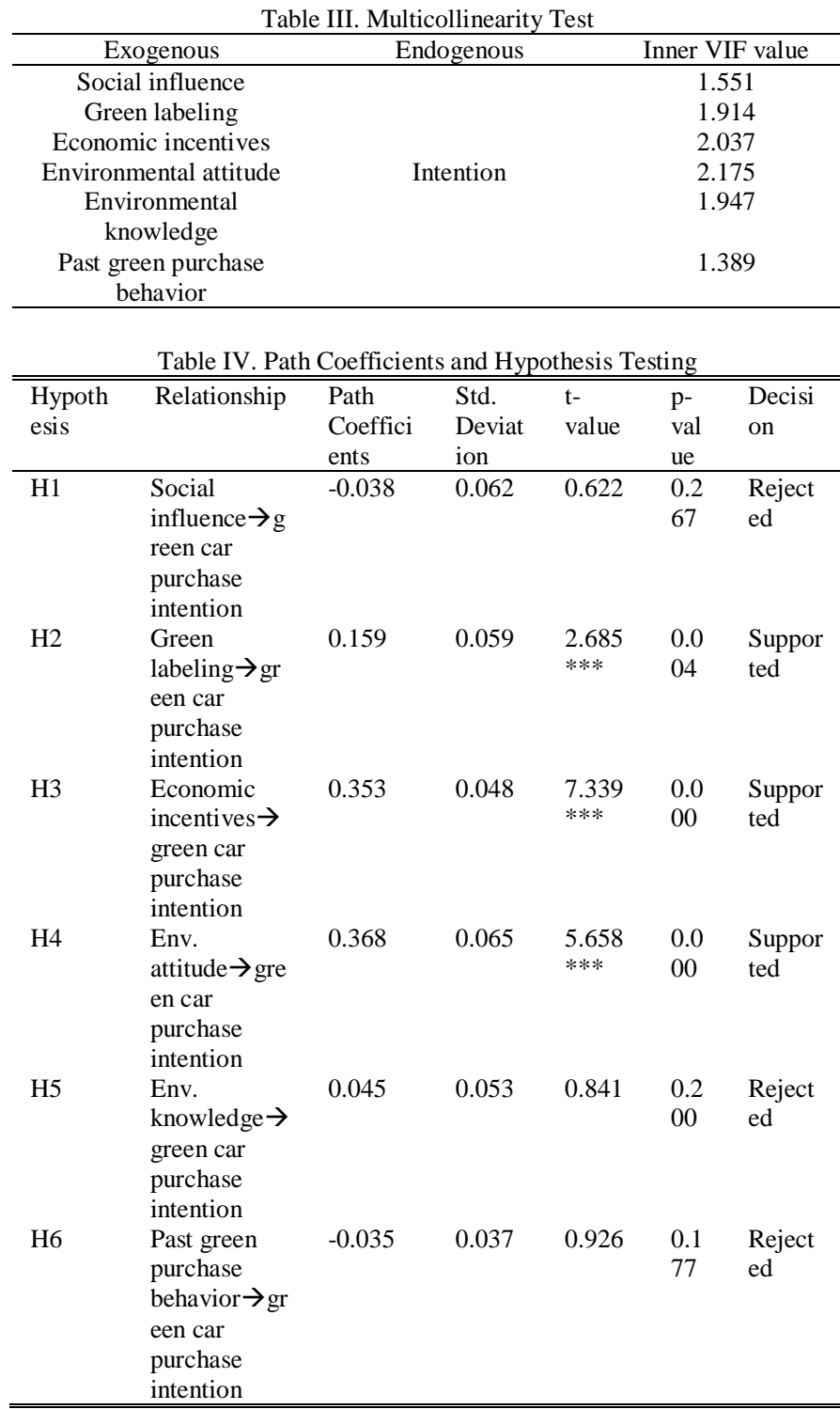

The model's predictive accuracy can be assessed using coefficient of determination score $\left(\mathrm{R}^{2}\right)$. As seen in Figure 1, the $R^{2}$ value of 0.541 were larger than 0.26 which signified a substantial model [74] with the exogenous variables (social influence, green labeling, economic incentives, environmental attitude, environmental knowledge and past green purchase behavior) explained $54.1 \%$ of the variance in green car purchase intention.

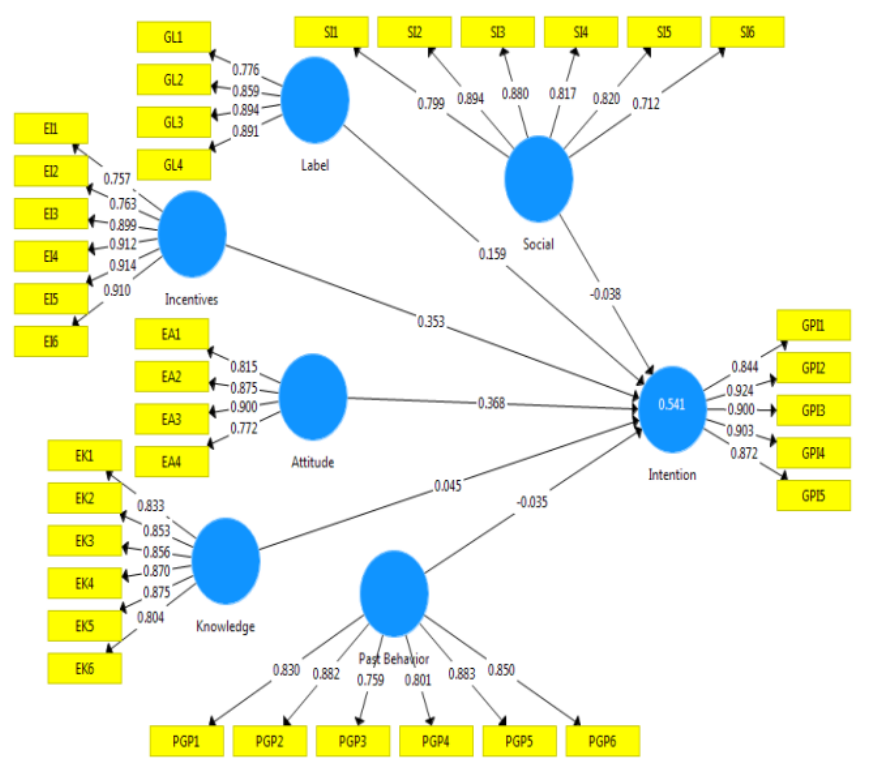

Fig. 1 Path Model: Item Loading, Path Coefficient, Level of $\mathrm{R}^{2}$

\section{CONCLUSION}

\section{A. Implications of the Study}

The current study presents the major indicators of green car purchase intention and can be beneficial for marketers in designing suitable marketing strategies for inducing green car purchase intention among the consumers in Malaysia. The empirical results of this study provide sufficient evidence to justify the relationships identified between the constructs of this study. Over and above, green car purchase intention was significantly influenced by green labeling, economic incentives and environmental attitude. The most significant influence was observed to arise from environmental attitude which emerged as the strongest indicators of green car purchase intention. This implies that marketers need to focus on developing consumers' positive environmental attitude especially towards the usage of green cars. The marketers can promote positive environmental attitude by disseminating the benefits of using green cars such as fuel saving as compared to full gasoline powered car and benefits of using green cars that emitted less carbon dioxide $\left(\mathrm{CO}_{2}\right)$ that subsequently protect the environment from getting worsen.

Economic incentives are also one of the important elements to influence consumers' purchase intention of green cars. Based on the findings, most of the consumers would consider buying green car if fuel price continue to rise, strict laws enforced on cars' tail emissions, subsidies are provided for $\mathrm{CBU}$ green cars, interest-free loan is provided, more subsidies would be more than provided now for CKD green cars and discount are offered for the insurance of green car. This implies that consumers in Malaysia would be more willing to adopt green car if these benefits are to be provided by the government together with the cooperation from the marketers. It has been proven by [35] that green car adoption is highly depends on the size of the incentives provided as could be seen from Norway that provided strong incentives to motivate their citizens to purchase green cars. Another factor that has been identified that can influence green car purchase intention is green labeling. For instance, marketers should provide more 
information on the labeling of the cars by stressing on the key attributes of green cars such as how much fuel saving, car maintenance fees which are cheaper, green technologies that have been used and easy charging features, so that consumers can differentiate green cars from full gasoline powered cars.

Within the green industry, there is intense interest in identifying factors that can lead to green purchase intention. In short, the research model and three out of six antecedents; environmental attitude, economic incentives and green labeling were useful for green marketers to develop effective relationship marketing.

\section{B. Limitations and Suggestions}

As with any studies, although this research has several contributions as mentioned in previous section, the findings attained in this thesis exhibited some shortcomings. These limitations needed to be recognized while also seek opportunities for future research. Firstly, this study was conducted in green automotive sector of Malaysia which is categorized in high involvement product category. Thus, the findings of this study cannot be used to generalize to all green product categories, which includes those with lower retail values or categorized under low involvement green product categories such as green facial care products, organic foods, green clothing and so on. Hence, it is suggested to examine low involvement green product categories and compare the results between high involvement green product categories and low involvement green product categories. Secondly, this study adopted cross-sectional research design to test the proposed hypothesized relationships which involves interview a fresh sample of people each time they are executed. Therefore, it does not allow the evaluation on the effects of social influence, green labeling, economic incentives, environmental attitude, environmental knowledge and past green purchase behavior toward green car purchase intention over a period of time. To cope with this problem, longitudinal study is recommended for future study to better understand the green car purchase intention phenomenon. Lastly, though the sampling of this study was chosen based on several factors such as states with highest population density, number of cars per square kilometer (KM), intention to purchase cars, car ownerships and so forth, it was confined to city limits based on the urbanization level in that states that assumed to produce higher pollution levels. However, this study does not take into account some other semi urban areas or rural areas that might generate different results which would be interesting to discover. Hence, future researchers are suggested to include wider geographical areas in order to generalized to all consumers in Malaysia.

\section{Conclusion}

Malaysia is a developing country that possess great potential for sustainable products as people nowadays are moving towards sustainable lifestyle. However, international green marketers especially those involve green automotive face difficulty when engaging Malaysian shoppers because there is limited data is available pertaining to their green car purchase patterns. The present study contributes to existing body of knowledge by evaluating the predictive influence of important variables that tailored to Malaysian consumers to obtain full picture of green car purchase intention among them. Over and above, the findings of this study showed that environmental attitude, economic incentives and green labeling significantly predict green car purchase intention. However, environmental knowledge, past green purchase behavior and social influence did not have direct significant effect on green car purchase intention. The results suggested that the effects of environmental attitude, economic incentives and green labeling might outweigh the effects of the other three variables.

\section{REFERENCES}

[1] Silitonga, A., Atabani, A., \& Mahlia, T. (2012). Review on fuel economy standard and label for vehicle in selected ASEAN countries. Renewable and Sustainable Energy Reviews, 16, 1683-1695.

[2] Ministry of International Trade and Industry. (2018). Updates on The Automotive Industry 2017 and Outlook in 2018. Putrajaya: Ministry of International Trade and Industry.

[3] Rezvani, Z., Jansson, J., \& Bodin, J. (2015). Advances in consumer electric vehicle adoption research: A review and research agenda. Transportation Research Part D, 34, 122-136.

[4] The Star Online. (2013, December 29). Drive on Hybrid Cars may Falter. Retrieved from The Star Online Website: https://www.thestar.com.my/news/nation/2013/12/29/drive-onhybrid-cars-may-falter-industry-players-want-tax-exemptionextended/

[5] Oliver, J. D., \& Rosen, D. E. (2010). Applying the environmental propensity framework: A Segmented Approach to hybrid electric vehicle marketing strategies. Journal of Marketing Theory and Practice, 18(4), 377-393.

[6] MyCarsearch. (2017, July 20). 3 Reasons Why Electric Vehicle (EV) is still Irrelevant for Malaysian. Retrieved from Mycarsearch: https://mycarsearch.my/news/84-3-reasons-why-electric-vehicle-evis-still-irrelevant-for-malaysian

[7] Schlegelmilch, B. B., Bohlen, G. M., \& Diamantopoulos, A. (1996). The link between green purchasing decisions and measures of environmental consciousness. European Journal of Marketing, 30(5), 35-55.

[8] Joshi, Y., \& Rahman, Z. (2016). Predictors of young consumer's green purchase behavior. Management of Environmental Quality: An International Journal, 27(4), 452-472.

[9] Lee, K. (2014). Predictors of sustainable consumption among young educated consumers in Hong Kong. Journal of International Consumer Marketing, 26, 217-238.

[10] Zhang, L., Chen, L., Wu, Z., Zhang, S., \& Song, H. (2018). Investigating young consumers' purchasing intention of green housing in China. Sustainability, 10(1044), 1-15.

[11] Joshi, Y., \& Rahman, Z. (2015). Factors Affecting Green Purchase Behaviour and Future Research Directions. International Strategic Management Review, 3(1/2), 128-143.

[12] Ajzen, I. (1985). From Intentions to Actions: A Theory of Planned Behavior. In J. Kuhl, \& J. Beckmann, Action Control: From Cognition to Behavior (pp. 11-39). Berlin, Heidelberg: Spinger.

[13] Kim, H. Y., \& Chung, J.-E. (2011). Consumer purchase intention for organic personal care products. Journal of Consumer Marketing, 28(1), 40-47.

[14] Mun, T. S. (2014). Factors that Influence Green Purchase Behaviour of Malaysian Consumers. Kampar: Universiti Tunku Abdul Rahman.

[15] Sinnappan, P., \& Rahman, A. A. (2011). Antecedents of green purchasing behavior among Malaysian consumers. International Business Management, 5(3), 129-139.

[16] Martin, C. A., \& Bush, A. J. (2000). Do role models influence teenagers' purchase intentions and behavior? Journal of Consumer Marketing, 17(5), 441-453.

[17] Kumar, P., \& Ghodeswar, B. M. (2015). Factors affecting consumers' green product purchase decisions. Marketing Intelligence \& Planning, 33(3), 330-347.

[18] Bertrandias, L., \& Gambier, L. E. (2014). Others' environmental concern as a social determinant of green buying. Journal of Consumer Marketing, 31(6/7), 417-429.

[19] Goldsmith, E. B., \& Goldsmith, R. E. (2011). Social influence and sustainability in households. International Journal of Consumer Studies, 35(2), 117-121. 
[20] Joshi, Y., \& Rahman, Z. (2017). Investigating the determinants of consumers' sustainable purchase behaviour. Sustainable Production and Consumption, 10, 110-120.

[21] Lee, K. (2011). The green purchase behavior of Hong Kong young consumers: The role of peer influence, local environmental involvement, and concrete environmental knowledge. Journal of International Consumer Marketing, 23(1), 21-44.

[22] Liobikiene, G., Mandravickaite, J., \& Bernatoniene, J. (2016). Theory of planned behavior approach to understand the green purchasing behavior in the EU: A cross-cultural study. Ecological Economics, $125,38-46$

[23] Smith, N. C., Palazzo, G., \& Bhattacharya. (2010). Marketing's Consequences: Stakeholder Marketing and Supply Chain Corporate Social Responsibility Issues. Business Ethics Quarterly, 20(4), 617 641

[24] Pudaruth, S., Juwaheer, T. D., \& Seewoo, Y. D. (2015). Gender-based differences in understanding the purchasing patterns of eco-friendly cosmetics and beauty care products in Mauritius: a study of femaile customers. Social Responsibility Journal, 11(1), 179-198.

[25] Delafrooz, N., Taleghani, M., \& Nouri, B. (2014). Effect of green marketing on consumer purchase behavior. Qscience Connect" A Qatar Foundation Academic Journal, 5, 1-9.

[26] Hall, C., \& Osses, F. (2013). A review to inform understanding of the use of food safety messages on food labels. International Journal of Consumer Studies, 37(4), 422-432.

[27] Bandara, B., Silva, D. D., Maduwanthi, B., \& Warunasinghe, W. I. (2016). Impact of food labeling information on consumer purchasing decision: with special reference to faculty of Agricultural Sciences. International Conference of Sabaragamuwa University of Sri Lanka 2015 (ICSUSL 2015). 6, pp. 309-313. Sri Lanka: Elsevier Ltd.

[28] Chekima, B., Wafa, S. A., Igau, O., \& Chekima, S. (2015). Determinant factors of consumers' green purchase intention: The moderating role of environmental advertising. Asian Social Science, 11(10), 318-329.

[29] Kong, W., Harun, A., Sulong, R. S., \& Lily, J. (2014). The influence of consumers' perception of green products on green purchase intention. International Journal of Asian Social Science, 4(8), 924 939

[30] Juwaheer, T. D., Pudaruth, S., \& Noyaux, M. M. (2012). Analysing the impact of green marketing strategies on consumer purchasing patterns in Mauritius. World Journal of Entrepreneurship, Management and Sustainable Development, 8(1), 36-59.

[31] Rahbar, E., \& Wahid, N. A. (2011). Investigation of green marketing tools' effect on consumers' purchase behavior. Business Strategy Series, 12(2), 73-83.

[32] Azizan, S. A., \& Suki, N. M. (2014). The Potential for Greener Consumption: Some Insights from Malaysia. Mediterranean Journal of Social Sciences, 5(16), 11-17.

[33] Beder, S. (2001). Economic incentives for environmental protection. Ecodate, 15(3), 6-7.

[34] Dini, A. (2018). Influence of New Car Buyers' Purchase Experience on Plug-in Electric Vehicle Demand. Brisbane, Queensland: Queensland University of Technology.

[35] Bjerkan, K. Y., Nørbech, T. E., \& Nordtømme, M. E. (2016). Incentives for promoting Battery Electric Vehicle (BEV) adoption in Norway. Transportation Research Part D: Transport and Environment, 43, 169-180.

[36] The Local Norway. (2018, May 31). Global Electric Car sales up in 2017, Norwat has Highest market share: IEA. Retrieved from The Local Norway: https://www.thelocal.no/20180531/global-electric-carsales-up-in-2017-norway-has-highest-market-share-iea

[37] Cheah, I., Phau, I., \& Liang, J. (2015). Factors influencing consumers' attitudes and purchase intentions of e-deals. Marketing Intelligence \& Planning, 33(5), 763-783.

[38] Yeoh, M., \& Paladino, A. (2013). Prestige and environmental behaviors: Does branding matter? Journal of Brand Management 20(4), 333-349.

[39] Felix, R., \& Braunsberger, K. (2016). I believe therefore I care: The relationship between religiosity, environmental attitudes, and green product purchase in Mexico. International Marketing Review, 33(1), 137-155.

[40] Almossawi, M. (2014). Promoting green purchase behavior to the youth (Case of Bahrain). British Journal of Marketing Studies, 2(5), $1-16$

[41] Shahnaei, S. (2012). The impact of individual differences on green purchasing of Malaysian consumers. International Journal of Business and Social Science, 3(16), 132-140.
[42] Gupta, S., \& Ogden, D. T. (2009). To buy or not to buy? A social dilemma perspective on green buying. Journal of Consumer Marketing, 26(6), 376-391.

[43] Moser, A. K. (2015). Thinking green, buying green? Drivers of proenvironmental purchasing behavior. Journal of Consumer Marketing, 32(3), 167-175.

[44] Moser, A. K. (2016). Buying organic - decision-making heuristics and empirical evidence from Germany. Journal of Consumer Marketing, 33(7), 552-561.

[45] Esakki, T. (2017). Green Marketing and Environmental Responsibility in Modern Corporations. Hershey: IGI Global.

[46] Gleim, M., \& Lawson, S. J. (2014). Spanning the gap: an examination of the factors leading to the green gap. Journal of Consumer Marketing, 31(6/7), 503-514.

[47] Tan, B.-C., \& Lau, T.-C. (2011). Green purchase behavior: Examining the influence of green environmental attitude, perceived consumer effectiveness and specific green purchase attitude. Australian Journal of Basic and Applied Sciences, 5(8), 559-567.

[48] Wahid, N. A., Rahbar, E., \& Shyan, T. S. (2011). Factors influencing the green purchase behavior of Penang Environmental Volunteers. International Business Management, 5(1), 38-49.

[49] Kianpour, K., Anvari, R., Jusoh, A., \& Othman, M. F. (2014). Important motivators for buying green products. Intangible Capital 10(5), 873-896.

[50] Göçer, A., \& Oflaç, B. S. (2017). Understanding young consumers' tendencies regarding eco-labelled products. Asia Pacific Journal of Marketing and Logistics, 29(1), 80-97.

[51] Goh, S., \& Balaji, M. (2016). Linking green skepticism to green purchase behavior. Cleaner Production, 131, 629-638.

[52] Kanchanapibul, M., Lacka, E., Wang, X., \& Chan, H. (2014). An empirical investigation of green purchase behaviour among the young generation. Journal of Cleaner Production, 66, 528-536.

[53] Mohiuddin, M., Mamun, A. A., Syed, F. A., Masud, M. M., \& Su, Z. (2018). Environmental knowledge, awareness, and business school students' intentions to purchase green vehicles in emerging countries. Sustainability, 10(1534), 1-18

[54] Wang, Y., \& Hazen, B. T. (2016). Consumer product knowledge and intention to purchase remanufactured products. International Journal of Production Economics, 181, 460-469.

[55] Han, T.-I., \& Stoel, L. (2016). The effect of social norms and product knowledge on purchase of organic cotton and fair trade. Journal of Global Fashion Marketing, 7(2), 89-102.

[56] Ha-Brookshire, J. E., \& Norum, P. S. (2011). Willingness to pay for socially responsible products: case of cotton apparel. Journal of Consumer Marketing, 28(5), 344-353.

[57] Sommer, L. (2011). The theory of planned behavior and the impact of past behavior. Intenational Business \& Economics Research Journal, 10(1), 91-110.

[58] Marx-Pienaar, N. J. \& Erasmus, A. C. (2014). Status consciousness and knowledge as potential impediments of households' sustainable consumption practices of fresh produce amidst times of climate change. International Journal of Consumer Studies, 38(4), 419-426.

[59] Lanzini, P., \& Thøgersen, J. (2014). Behavioral spillover in the environmental domain: An intervention study. Journal of Environmental Psychology, 40, 381-390.

[60] Khare, A., \& Varshneya, G. (2017). Antecedents to organic cotton clothing purchase behaviour: study on Indian youth. Journal of Fashion Marketing and Management: An International Journal, 21(1), 51-69.

[61] Kwon, W.-S., \& Noh, M. (2010). The influence of prior experience and age on mature consumers' perceptions and intentions of internet apparel shopping. Journal of Fashion Marketing and Management An International Journal, 14(3), 335-349.

[62] Yeo, V. C., Goh, S.-K., \& Rezaei, S. (2017). Consumer experiences, attitude and behavioral intention toward online food delivery (OFD) services. Journal of Retailing and Consumer Services, 35, 150-162.

[63] Carrus, G., Passafaro, P., \& Bonnes, M. (2008). Emotions, habits and rational choices in ecological behaviours: The case of recycling and use of public transportation. Journal of Environmental Psychology, 28, 51-62.

[64] Huang, Y. C., Yang, M., \& Wang, Y.-C. (2014). Effects of green brand on green purchase intention. Marketing Intelligence \& Planning, 32(3), 250-268.

[65] Moons, I., \& Pelsmacker, P. D. (2012). Emotions as determinants of electric car usage intention. Journal of Marketing Management, 28(34), 195-237.

[66] Lee, K. (2009). Gender differences in Hong Kong adolescent consumers' green purchasing behavior. Journal of Consumer Marketing, 26(2), 87-96. 
[67] Qu, Y., Liu, Y., Zhu, Q., \& Liu, Y. (2014). Motivating smalldisplacement car purchasing in China. Transportation Research Part A, 67, 47-58.

[68] Morton, C., Anable, J., \& Nelson, J. D. (2016). Accessing the importance of car meanings and attitudes in consumer evaluations of electric vehicles. Energy Efficiency, 9(2), 495-509.

[69] Urbach, N., \& Ahlemann, F. (2010). Structural equation modeling in information systems research using partial least squares. Journal of Information Technology Theory and Application (JITTA), 11(2), 5.

[70] Hair, J., Hult, G. M., Ringle, C. M., \& Sarstedt, M. (2017). A Primer on Partial Least Squares Structural Equation Modeling (PLS-SEM). Thousand Oaks, US: SAGE Publications.

[71] Hair, J. F., Black, W. C., Babin, B. J., \& Anderson, R. E. (2010) Multivariate Data Analysis (7th ed.). Pearson.

[72] Diamantopoulos, A., \& Siguaw, J. A. (2006). Formative versus reflective indicators in organizational measure development: A comparison and empirical illustration. Bristish Journal of Management, 17(4), 263-282.

[73] Ramayah, T., Cheah, J., Chuah, F., Ting, H., \& Memon, M. A (2018). Partial Least Squares Structural Equation Modeling (PLSSEM) using SmartPLS 3.0 (2nd ed.). Kuala Lumpur: Pearson.

[74] Cohen, J. (1988). Statistical Power Analysis for the Behavioral Sciences. Hillsdale, NJ: Lawrence Erlbaum Associates.

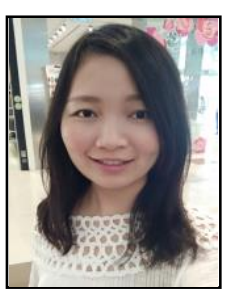

Yi Jin Lim was born in Kedah, Malaysia, in 1989.She obtained her diploma in retailing from Polytechnic Ungku Omar, Perak, Malaysia in 2010 and Bachelor degree in International Business from Universiti Malaysia Perlis (UniMAP), Perlis, Malaysia in 2013. In the same year, she continued her study in Master of Science, major in marketing at the same university and had graduated in 2015. She is currently further her study in $\mathrm{PhD}$ degree, major in Sintok, Kedah, Malaysia. marketing at Universiti Utara Malaysia (UUM) in

She has been published 12 articles including 5 co-authorship articles so far. The most recent publications were titled as "Factors Influencing Online Shopping Behavior: The Mediating Role of Purchase Intention" and Importance of Trust Towards University Students: A Determinants of Online Shopping Behavior". 